\title{
TRANS-RELIGIOUS IDENTITY FROM THE EDGE? Promoting Interfaith Dialogue among Transgender Community in Yogyakarta
}

\author{
Achmad Fawaid \\ IAI Nurul Jadid Paiton Probolinggo \\ Email: fawaidachmad@gmail.com
}

\begin{abstract}
Transgender issues, including those who have been called as 'waria', are diverse, complex, and evolving, particularly in Indonesia where the most inhabited people are Muslims commonly bringing with them any sexual and, sadly, religious streotype to waria as marginal(ized) individuals. This paper aims to raise a question of our primordial understanding and religious experience on the existence of transgender community. It focused on an empirical study of Kebaya (Keluarga Besar Komunitas Waria Yogyakarta), Yogyakarta's Center for Transgendered, which is an NGO developed by transvestites in Yogyakarta to strunggle against prejudice, acceptance, and HIV Aids. This study is not specificly to analyze their social relation, but importantly how the NGO became a shared space of interfaith dialogue and a representation of religios life among transgender people in Yogyakarta, including the ways they build socio-cultural-religious relation with other people and religious figures. It would be analyzed under socio-anthropological approach to religion by which this study reflect them as a part of certain community who had special position in terms of interreligious dialogue. The implication of this study suggests that interfaith dialogue is possible, not only among the inner-circle of mainstream religious believers, but also among and from the edge community: from those who often feel ostracized within today's trans-population in Indonesia.
\end{abstract}

Keywords: transgender community, interreligious dialogue, Kebaya

\section{INTRODUCTION}

The relationship between transgender and religion varies widely around the world. Religions range from condemning any gender variance to honoring transgender people as religious leader. In Indonesia, promoting interreligious tolerance, dialogue, and sympathy among transgender people are challanging but too risky, since the most conservative Muslims and believers in this country had accused them as having to do with sexual orientation rather than identity. ${ }^{2}$ What's special about transgender people is their self-understanding

\footnotetext{
${ }^{2}$ Koeswinarno, "Islamic Response to Transexuality in Indonesia", a paper presented in Southeast Asian Consorsium on Gender, Sexuality, and Sexual Health, (Salaya, Thailand, 2003),
} 
and self-expression when it comes to gender with religion.

There are two general types of binary gender (male and female), and waria is regarded as the third gender. However, the term waria, in some extents, is problematic. It could be related to the extent to which waria is socially perceived in the certain communities. In the toilets of TRS (Taman Remaja Surabaya), for instance, waria's identity seems to be adjusted with male (pria), not female (wanita). There are only two toilets there indicating: "wanita" dan "pria/waria".

It means that waria is not a kind of gender category apart from both of them. Tom Boellstroff refers waria to male transvestites or male transgender. ${ }^{4}$ Transgender people also include persons with intersex conditions, such as external genitalia not easily classified as male or female, variant development of internal reproductive organs or variations in sex chromosomes. ${ }^{5}$ Consequently, they have inflexible attitude; their bodies are men, but the ways they walk, talk, and dress up are like women. ${ }^{6}$

Ben Murtagh, in Genders and Sexualities in Indonesian Cinema (2013), quoted a pyschiatrist's definition of the three types of transgender, or commonly called in Indonesia as wadam or banci:

The first is the transsexual (transexualisme) group, that is those who have the body of men but the souls of women. The second is the transvestite group (transvestisme), who are those who have the bodies of men but get sexual pleasure by performing the activities of women or those who have feminine characteristics. The third group is known as wadam kaleng, or banci kaleng. That is men who wear women's clothes for profit or who merely have an adventurous spirit.?

p. 2. The short of it is that Islamic law forbids men to dress and adopt the mannerisms of women, and vice versa. Unsurprisingly, the image of a bunch of transsexuals facing Mecca with their dicks dangling underneath their jilbāb gives some parts of Islamic society the heebie-jeebies. Not only in Islam, the conservative Christian people commonly note that the Book of Genesis in the Hebrew Scriptures (a.k.a. Old Testament) describe how God created Adam as a male and Eve as a female. Many conservatives feel that God restricted each gender to specific roles in the family, faith group, government, and other areas of life. They may feel threatened by thoughts of a newborn being created by God as being of one gender and then having that person change gender later in life: 'gender confused'.

${ }^{3}$ Tom Boellstroff, "Playing Back in the Nation: Waria, Indonesia Transvesties", Cultural Anthropology. Vol. 19, No. 2 (May, 2004), p. 182.

${ }^{4}$ Ibid, p. 161-162.

${ }^{5}$ Chris Glaser, "Gender Identity and Our Faith Community," A Guide for Advocacy, published by Human RIght Campaign. Online download: http://www.hrc.org/resources/ gender-identity-and-our-faith-communities-a-congregational-guide-for-transg. (The last access: August 15th, 2016). This guide had strongly contributed to idea of this paper in terms of promoting trans-religious identity among transgender community.

${ }^{6}$ Koeswinarno, Hidup Sebagai Waria (Yogyakarta: LKiS, 2004), pp. 1-5

${ }^{7}$ Ben Murtagh, Genders and Sexualities in Indonesian Cinema: Contructing Gay, Lesbi, and 
Shortly, the term waria is an amalgamation of the Indonesian word for woman, wanita, and the word for man, pria, which has been coined to describe the transgendered population in Indonesia. These days in Yogyakarta society has buttonholed its warias into a specific category of entertainers (namely buskers and street artists), beauticians and sex workers, because they are deemed socially unacceptable in other professions.

Waria's life in Indonesia has a long story. A historical tradition of Gemblak or Ludruk in East Java suggests that there were women acted by men. In such tradition, they have a cultural position in the light of art performance, but they have socially been marginalized because they are often associated with prostitution. ${ }^{8}$

Today it is ironically recognized that there is lack of exact calculation on amount of waria in Yogyakarta. Firstly, no institutions, either private or state, carefully collected data of waria. The social board (Dinas Sosial) of Yogyakarta never made an inventory database of their life. Secondly, the main organization of waria, known as Iwayo (Ikatan Waria Yogyakarta), ${ }^{9}$ has not been followed by majority of waria in Yogyakarta, as it is difficult to get an access about numbers of waria. Thirdly, waria is a community with high mobility, since many warias in Yogyakarta are immigrants from other cities.

The social rejection highly contributed to the unacceptable and marginalized condition of waria. There is also politization of identity in which waria has insufficient bargaining position to be voter or political leader. The unclear card identity, difficult profession, social stereotype, and small amount of quantity are common causes of social distrust to them in the level of political government. ${ }^{10}$ The human right is another issue mostly associated to waria. The discrimination to them has still occurred, as some NGOs which concern

Waria Identities on Screen, (Abingdon, Oxon, New York: Routledge, 2003), p. 33.

${ }^{8}$ Koeswinarno, Waria dan Penyakit Menular Seksual, (Yogyakarta: Pusat Penelitian Kependudukan UGM, 1996), pp. 12-14.

${ }^{9}$ The (f)actualization of waria in Yogyarkata society occurred in June, 1980. At that time, an artist, the late Yoyok Aryo succeed to gather waria around Yogyakarta and contacted Persatuan Wartawan Indonesia (PWI) Yogyakarta branch on June $13^{\text {th }}, 1980$ to declare community of DIY Waria. However, program's intensity of community slowly decreased until it transformed into newer community called Iwayo (Ikatan Waria Yogyakarta) leaded by Christine Tambroni. Main focused agenda of this community is social agendas for waria. Koeswinarno, ibid, pp. 64-65. Later, on December $18^{\text {th }}$, 2006, due to massive cases of HIV/ AIDS suffered waria, Kebaya (Keluarga Besar Komunitas Waria) was built to deal with it. This NGO also advocates empowerment and protection to waria with HIV/AIDS.

${ }^{10}$ Koeswinarno, "Islamic Response to Transexuality in Indonesia", a paper presented in Konsorsium on Gender, Sexuality, and Sexual Health in Southeast Asia, Salaya, Thailand, 2003. This work focused two major studies: Islamic law and Muslims' social response to the existence of waria, and their influence on production of social streotype to the boarder transgender community in Indonesia. 
about humanity and gender attempted to advocate them for better social relation. However, social discrimination has been unfinished hitherto.

Among these crucial issues, there is rarely discussed one: inter-religious issue. It is important to notice that waria is commonly regarded as people with transgender characteristics, HIV/AIDS, and other social stereotypes, such as bancing, bencong, and the like. However, it is considerable to question on their religious life. Are they religious community? How do they conduct interreligious dialogue with elites of religious groups?

These questions are inteded to stimulate further exploration of their religious lives. It has been also guide-assistance for this research in perceiving waria in the light of religious perspective. Waria are positioned as people who have certain religious values and practices. However, there are some exceptions by which waria are commonly called as "non-religious" or "confused-religious" or "blasphemed-religious" people with the different ways.

This research is aimed to study whole population of waria in Yogyakarta. The samples are represented into community based waria, Kebaya (Keluarga Besar Komunitas Waria), an NGO concerning about empowerment of waria and dealing with HIV/AIDS care. The former and executive of the community, Mami VK, has argued that Kebaya is historically an extension of Iwayo (Ikatan Waria Yogyakarta) built on May 1st, 1983. In Kebaya, there are four members with different religions. ${ }^{11}$ However, as Mami VK said, they have full respect to their own religious experiences among each other.

The inter-religious issue is sensitive but important problem to discuss in a relation with waria community in Yogyakarta. This is sensitive due to fact that in recent development, the members of Kebaya are still difficult to worship outside of their own community, so it is important to discover how they interact with the others in the context of religious activities. This research is aimed, one of them, to portray this issue.

\section{LITERATURE REVIEW}

The research themes concerning with waria, or transgender in general, have been commonly discussed in the field of medical, political, social, and cultural aspects. However, interreligious issues withing this spectrum of literatures are rarely under main analysis. Some sources are highly contributing to this research. Koeswinarno's seminal works, Hidup Menjadi Waria (2004) $)^{12}$ and Waria dan Penyakit Menular Seksual (1996) are primary sources initially

${ }^{11}$ They are SR, AJ, and WN (Moslems) and KR (Christian).

${ }^{12}$ Koeswinarno, Hidup Sebagai Waria (Yogyakarta: LKiS, 2004). 
exploring waria's life in Yogyakarta. A major theme of these books is sociocultural arena related to future of waria. For Koeswinarno, waria has low social acceptance as "normal" community, so they should reformulate their strategies to survive in the future. There would be two remaining choices: become homosexual or genital circumscision. This book is important in building the initial framework for this study, but Koewinarno does not discuss in more details the inter-religious experiences of waria in Yogyakarta.

In Gender, Sexualities in Indonesian Cinema: Constructing Gay, Lesbi, and Waria Identities on Screen (2003), Ben Murtagh explores how lesbian, gay, and transgender subjectivities have been portrayed, and understood, in Indonesian cinema from 1971 until 2008, such as Gadis Metropologis, Istana Kecantikan, and Arisan!. By queer viewing of these film, Murtagh resulted in a valuable contribution to understand gender and sexuality in Indonesia that will be rewarding read for all those interested in Indonesia, film, and queer subjectivities. In analysing films and revealing audience viewing strategies, Murtagh shows that films cannot simply be criticised as negative presentations or praised as positive ones, but rather that complexity characterises both production and viewing strategies. In Chapter 2, Murtagh explores portrayals of waria is removed to assert maeness over performative feminity. Although the films selected reveal a kind of normalness about being waria, Murtagh frames waria as asexual figures of fun, and consequently has little concern with their religious life.

Meanwhile, Tom Boellstorff, in his article "Playing Back the Nation: Waria, Indonesian Transvestites" (2004) ${ }^{13}$ has clearly explained social relation of waria in Taman Remaja Surabaya (TRS). Boellstrof perceived waria's subjectivity in the contested point of identity between male (pria) and female (wanita). For Boellstorff, TRS is a space in which waria identity is socially admitted. Boelstorff provides an example of toilet in TRS which is initially named with "wanita" dan "pria" in the nameplate, and now it has been changed into "wanita" dan "pria/waria". The result pointed out that in Indonesia; waria's subjectivity is commonly based on their performance, not their identity status. In this article, Boelstorff also clarifies a little bit of waria's perception about their God. For him, waria believed that "become waria" is a gift from God which can't be refused. This article is important for this research, but it does not futher explore the ways waria involved with interreligious dialogue with elites of religious groups.

Next year, after the previous article has been published, Tom Boellstorff did

${ }^{13}$ Tom Boellstor ff, "Playing Back in the Nation: Waria, Indonesia Transitives", Cultural Anthropology. Vol. 19, No. 2 (May, 2004), pp. 159-195. 
additional research of waria in the light of homosexuality in Indonesia. His article "Between Religion and Desire: Being Muslim and Gay in Indonesia" $(2005)^{14}$ provide an exploration of gays' perception and position in religion. Boellstorff attempts to discuss homosexuality in relation with religion, but the subject of his study is not waria, but gays. For Boellstorff, gay community has been more influenced by orthodoxy of Islamic doctrine which positioned them as part of Sodom. However, some of them have argued that what happens in them is a destiny that neither can't be changed nor refused. In some extents, this article is helpful for building a theoretical framework for this study in drawing a relationship between waria and religion, but in other extents it does not explain interreligious dialogue in which gays have been involved in their daily basis.

This research is exactly at position to provide a landscape of waria's religious patterns and their participation in building an interreligious dialogue with elites of religious groups. Regarding with some relevant literatures above, this study suggests that social stereotype, as Koeswinarno (2004) argued, is very influential on the ways waria perceives their God. This study is also affirmative to Murtagh and Boellstorff's works that waria believed that "become waria" is a blessed gift from God. However, this study resulted in different hypothesis from what Murtagh and Bollstorff did. In the case of sin, for instance, not all waria believe that "become waria" is a gift; some of them have been doubly said that "become waria" can be sinful under certain circumstances. This study also takes a different position from these sources in its analysis on how waria have conducted interreligious dialogue with elites of religious groups.

\section{A SHORT CAPTURE OF KEBAYA}

\section{Development and Institution}

In Yogyakarta Kebaya is the only Center for Transgendered People with its mission on empowerment of waria in social, cultural, and health care. Kebaya is an extension of Iwayo (Ikatan Waria Yogyakarta) built on May 1st, 1983. The transformation of Iwayo into Kebaya are result of the fact that Iwayo did not really concerned about HIV/AIDS issues in waria community.

The NGO with its notarial deed No. 38/22 January 2007 is aimed to reach a main goal: "Waria Yogyakarta Would Be Free from HIV/AIDS". This institution is based at Gowongan Lor JT III/148 Yogyakarta, approximately 30 meters from crossroads of Yogyakarta Monument. Like other NGOs, Kebaya is organized in the structural division, including Consultant (GKR Hemas, Dr.

${ }^{14}$ Tom Boellstroff, "Between Religion and Desire: Being Muslim and Gay in Indonesia”, American Anthropologist, New Series, Vol. 107, No. 4 (December, 2005), pp. 575-585. 
YW, S. Ph. D.), Director/Manager (Mami VK), Field Coordinator (AM), Case Manager (RM), Finance (YS), and Field Officers (YR, WA, TA, SA, SA).

Kebaya has been supported by its members' subsidies. It also builds institutional relationship with some funding, such as UNAIDS, HIVOS, and GF. Among many programs of Kebaya, the empowerment of waria with ODHA (Orang dengan HIV Aids/People with HIV Aids) is the most important. This community has conducted care-support treatments and VCT test regularly in the six areas of waria communities in Yogyakarta. ${ }^{15}$ In the scientific level, Kebaya has involved with both individual and collective researches about waria by means of making relation with some universities in Yogyakarta. It has also produced a documentary film about waria and waria photo exhibition.

\section{Religious Life}

Kebaya did not have a special program to cover religious based activities as well as religious background of every waria in the six places of Yogyakarta. Such agenda is challenging in the sense of that waria life could be regarded as "mysterious" or "non-panoptical". Instead of taking clear identity, today's debate is on adequacy of legal identity of gender in their identity cards.

However, it does not mean that Kebaya has no concerns with religious practices. Pesantren Al-Fatah is one of Islamic organizations together with Kebaya for development of waria. This Islamic institution is specialized for giving Islamic education to waria. Some lecturers of UIN Sunan Kalijaga have been involved in this institution. ${ }^{16}$ The Senin-Kamis school ("MondayThursday" in Indonesian, the two days of the week school is in session) is another religious institution founded in 2008 as a safe place for transgender Muslims to practice their faith without judgement or ridicule. ${ }^{17}$

Additionally, Kebaya also builds some initiatives of interreligious dialogue with some elites of religious groups. This is what will be further discussed on the special chapter. Generally speaking, the interreligious dialogue between

${ }^{15}$ In the data base profile, Kebaya stands with eight waria communities, such as Kricak Community (Sidomulyo) with 39 members, Badran Community with 19 members, Lempuyangan and Solo Street Community with 33 members, Sleman Community with 25 members, Bantuk Community with 42 members, and other communities with 71 members. What makes this database unique is because it only includes of name, place, and date of birth, home town, last educational level, and occupation. There is no information about religion in the data base. Kebaya Team, "Database Pendampingan Waria LSM Kebaya DIY Per-31 Mei 2011”, Yogyakarta: LSM Kebaya (unpublished).

${ }^{16}$ One of UIN Sunan Kalijaga lecturers actively involving in Al-Fatah Islamic Institution is Muzayyin, brother of Abdul Muiz Ghazali, an activist of Nahdlatul Ulama Indonesia.

17 More details on the Senin-Kamis school of waria are available on Hannah Brooks, "Warias, Come Out, and Plaaayayay", p. 1. 
Kebaya members and religious elites is not formal one in the ceremonial events. It takes a form of personal encounter between both of them.

Kebaya located at the housing in which most residents are Muslims. Kebaya building takes a place near to the Muslim family houses. My interview with Mami VK and some residents resulted in a fact that there is relatively no conflict between Kebaya members and their neighbors. Rather, the neighbors have high tolerance with the existence of this NGO in participating some empowerment events of waria in Yogyakarta.

There are four members living in this base camp. Three of them are Muslims, and another one is Christian. However, they are seemingly accommodated in harmonious relation each other. Moreover, for them, talking about "religion", is something "strange", because the religion is a private bussiness.

\section{"WARIA RELIGION AS TRANS-IDENTITY"18}

How to define waria religion? The term waria religion is not intended to indicate that waria's religion is different from religion which other people formally embrace. Instead, this term is used to emphasize the importance of religion for waria and to show that waria has own transcendental spirit just like other religious people.

The waria religion, here, is defined as trans-religious identities and patterns practiced by waria as well as the ways people responded them in social context. To further explain waria religion in a relation with interreligious dialogue, the first thing to do is to draw out their religious experiences in the term of worship, sin, and destiny, and then to seek for practical possibilities in which they are involved in interreligious dialogue with other waria, society, and elites of religious groups.

\section{Worship}

The transgender people, including waria, tend to define worship as personal activity. Although worship also has social impact, they find it risky to get this chance. It comes from the difficulties as well as dilemmas to perform worship in public places, such as in mosque or church. Mami VK told about how difficult for him, and other warias, to perform Friday prayer in the public mosque.

\footnotetext{
${ }^{18}$ Conceptually, term 'waria's religion' is modified from term agama pelacur popularized by Nur Syam in his Agama Pelacur: Dramaturgi Transendental (Yogyakarta: LKiS, 2011). In this book, Syam tried to discover religious life of a prostitute using social dramaturgy analysis. This subtitle is also trying to explain religious experience of waria, but the targeted output is about how the experience influences waria in building interreligious dialogue with elites of religious people.
} 
That is the problem (about performing prayer in mosque). I am confused how to behave. We don't perform Friday prayer not because we don't want to do it. We just think about how other people feel and think of us while performing Friday prayer. Instead of being focus in prayer, they will feel bothered enough. ${ }^{19}$

It suggests an unfinished social problem in waria's daily worship activity. Friday prayer for every Moslem male is 'obliged' not to perform because of social stereotype. However, the statement we just think about how people feel and think of us while praying implies a concession that every Muslim shouldn't do due to equality doctrine of all human being while practicing prayer.

Because of worship they perform tends to regard with their personal intimacy with God, command to perform worship is not obeyed with sense of compulsion at all. "For me, religion is about pleasantness in performing worships," ${ }^{20}$ Mami VK said. It also suggests that that waria, in some extents, is more religious than common religious people. During observation, Mami VK seems never force or commands other warias to perform prayers even though Mami VK was born in a strong religious family.

"You all are Moslems, so just do the prayers," is that Mami VK kept saying to Kebaya's members. It points out that actually waria's religious responsibility to God is strong enough. Although they are marginalized in social life, they still consider and do believe in God's existence as an ultimate source for every gift and things they have now.

\section{Sin}

Warias have different interpretation of a sin. At least, based on their interpretation, they can be divided into two categories, i.e. those who consider that being waria is sinful, and others who think that it doesn't matter to be waria (in other word, the later category seems to consider that waria is a blessed destiny).

The former group is mainly influenced by Islamic doctrine of Lot's story and Sodom people. Although some verses talking about Prophet Lot's story are still problematic, they really influence the way waria look at themselves as well as interpret the meaning of sin especially in taking sexual intercourse with the same sex..$^{21}$

\footnotetext{
${ }^{19}$ Interview with Mami VK, on February 20, 2014, at Kebaya basecamp.

20 Interview with Mami VK, on February 20, 2014, at Kebaya basecamp.

${ }^{21}$ Due to Islamic perspective, zina or adultery is generally defined as illegal relationship between men and women, while anal sex which is usually performed with the same sex is sinful. However, sinful aspect of those two practices need to be further discussed and explained,
} 
Well, based on Lot's story, we are not Sodom people. Sodom consists of gay and lesbian instead of waria. Those people wanted to take sexual intercourse with Angels, but we don't want the same. We liked to do it with handsome men. It is undeniable about strange feeling when I listen to the story. Feeling guilty and sinful is probably true, but it is the destiny. Then what should we do? ${ }^{22}$

It suggests that Lot's story still influences on the ways waria makes a meaning, understand, and interpret a sin. Here, essence of sin is specially interpreted in a matter of sexual relation no matter what the condition beyond the relation is, such as amounts of sexual partners or treatment during the sexual activity. However, there is also waria who interprets the sin in practical frame. In our short conversation, $\mathrm{WN}$ told:

I think it depends on your deeds. Generally, all religions dislike us. However, in a matter of sinful or not, it is all about choice. If both parts in any relation are willing to do, there is no sin then. But, taking sexual intercourse with several partners may be sinful, because it is also bad for health. ${ }^{23}$

A reasons behind such consideration of "sinful" waria is strongly practical. According to $\mathrm{WN}$, a matter of sin in being waria depends on how waria interacts with the partner. When both parts are glad and willing for the relationship, the sin can be decreased or erased at all. Meanwhile, for WN, waria can also get sin if for not keeping God's blessing by taking sexual intercourse with several partners which is so risky to suffer HIV/AIDS.

\section{Destiny}

This is actually regarded with previous depiction on whether it is sinful to be a waria. In this case, warias usually assume that 'being waria' is not sinful, because it is a destiny even a God's blessing.

God created them as warias for His own will and they can't neither deny nor reject it. Refusing God's gift is precisely a sinful thing, because God has determined them to be waria. So that's why, there is no reason to say that being

because Al-Quran only mentions Lot's people instead of Sodomi or Gomorrah. Meaning to say, homosexual relationship is excluded in sinful actions category. Stephen O. Murray and Will Roscoe, "Conclusion", Islamic Homosexuality: Culture, History and Literature, eds. Murray and Roscoe, New York: New York University Press, 1997, p. 307.

${ }^{22}$ Interview with SR, February 20, 2014, at Kebaya base camp.

${ }^{23}$ Interview with WN, February 20, 2014, at Kebaya basecamp. 
waria is a sinful one.

I am not willing to be a waria, but this is God's gift. I never tried to change my self into a woman, but since I was a child, I had had feminine characters. Therefore, I just want to keep the body and soul God gave me. There are few people who intentionally change penis into vagina, such as Dorce. I don't want to be like them. This is a God's gift, I will never change it. I will keep it as always. ${ }^{24}$

What Mami VK told above suggests that being a waria is not sinful, because it is God The Most Merciful's blessed gift. As a waria, Mami VK believes that none dreamed or wanted to be waria, but since we was born, we was as we is and our fate is nothing but being a waria. Therefore, Mami VK just receives and keeps everything on his hand.

For Mami VK, sinfulness is not being a waria, but trying to change what God gave into something else which is different. Being a waria is a fate and everyone gets the fate has to receive what God wants them to be. About it, Mami VK firmly said.

If I changed my genital, would I get pregnant? Is it possible for me having womb? I wouldn't, would I? When the Angel asked me where the God's gift is, I will not able to answer if I had removed it. Otherwise, if I pass away, I will not care whether I will be showered in a way people use for female corpse or male one. I don't care at all. ${ }^{25}$

Mami VK's conviction about destiny is really important here, especially about waria's self confidence. Considering "being waria" as a destiny even blessing is a kind of last fort they have when they regret about themselves as well as what they done so far. This is also closely related with how they interpret sexuality essence as a part of desire, because everyone has a desire and denying it is just a sinful one.

\section{WARIA AND INTERFAITH DIALOGUE}

Kebaya is an active NGO involved with contributing and building interfaith dialogue with society, other warias, and elites of religious people at Yogyakarta. Surely here, the dialogue has three definitions. Firstly, dialogue and meeting

\footnotetext{
${ }^{24}$ Interview with Mami VK, February 20, 2013, at Kebaya basecamp.
}

${ }^{25}$ Interview with Mami VK, February 20, 2013, at Kebaya basecamp. 
of different perspective; secondly, concrete and real meeting with religious people; and thirdly, self-empowerment to open with the others in dialogue. By attending face to face dialogue, waria has actually involved in multi-perspective dialogue, between waria's perspective and religious people's perspective.

There are two perspectives used in defining interreligious dialogue. The first is coming from St. Sunardi's idea in "The Dead End of Religious Dialogue in Indonesia" (2001). ${ }^{26}$ For Sunardi, today's idea of dialogue is very limited. In Indonesia, the interreligious dialogue tends to be elitist, in which this activity is commonly undertaken and coordinated by the governmental institutions, including Minister of Religious Affairs. Consequently, the dialogue is merely aimed to protect the believers from proselytism (p. 67). According to Sunardi, the interreligious dialogue is ideally directed one of them, to make an encounter between religious communities and society. Such dialogue can advance not only religious consciousness, but also social collectiveness to deal with social issues in Indonesia.

The second is Mansour Fakih's idea of social transformation in his wellknown Jalan Lain: Manifesto Intelektual Organik (2002). ${ }^{27}$ In this book, Fakih has not directly mentioned "dialogue" as part of transformative movements. He has emphasized the importance of critical attitude to social change. What is expected from the interreligious dialogue should be aimed to achive such goal: social transformation. In Fakih's perspective of transformation, the interreligious dialogue is not merely regarded in normative way as a social encounter among religious communities. Such dialogue should be pragmatic in the sense of social transformation. For this purpose, those who are involved within the interreligious dialogue should have critical position to dominant party in social relation. The community of waria, for instance, is not merely guided to have dialogue, but also to empower them to have self-recognition about the importance of dialogue for social transformation.

Additionally, Kebaya also attended interreligious dialogues with various communties. Some of them are kyai, pastor, and FPI. Having each other's interest, those communities tried to have interreligious dialogue with Kebaya as an institution contributing to an empowernment of waria in various aspects. For the purpose of social transformation, Kebaya has actively been involved in empowering waria for self-recognition in building the interreligious dialogue with other religious community.

${ }^{26}$ Sunardi, “The Dead End of Religious Dialogue in Indonesia”, Interface 4, 1 Mei 2001, pp. 55-65.

${ }^{27}$ Mansour Fakih, Jalan Lain: Manifesto Intelektual Organik, (Yogyakarta: Pustaka Pelajar bekerja sama dengan Insist Press, 2002). 


\section{Waria and Kiai}

The history of Kebaya can't be separated with personal experience of Mami VK who often involves in founding and leading it up to now. During our interview, I could infer that personally Vinolia has a close relation either with kyai or pastor. In the midst of process for getting having self-identity, for instance, Mami VK ever visited a house of kyai in Yogyakarta. The kyai openly and warmly welcomed him and said, "it is ok to be waria as long as you do well for others".

However, not everyone accepts existence of waria. Some elites of religious people are still wondering waria's status in hereafter. Some radical kyais also often underestimate them by saying that waria only deserves place in hell to be tortured there. Once upon a time, Mami VK visited a religious figure and asked him to be repentant.

When he ordered us to read a verse, one of use was able to read it because he is alumnae of Tebuireng Islamic Boarding School. However, we were still blamed and accused. ${ }^{28}$

Dealing with this issue, Mami VK usually strengthens herself by visiting Islamic boarding schools welcoming her well. Fortunately, not every elite of religious people treat them badly.

"Kyai HM was even more opened and welcomed us better," Mami VK said. HM is a leader of Pesantren Senin-Kamis in Notoyudan, Ngampilan, Yogyakarta. The institution accepts waria, gay, and lesbian to be student living and studying there. This Islamic boarding school is initiated by Iwayo before it turned into Kebaya.

\section{Waria and Pastor}

Besides kyai, Kebaya members are also active in building interreligious relation with pastor. They actively involved in some meetings and events of Seminari School at Jakal (Kaliurang Road). At that time, Mami VK, discussed with some pastors and academicians about waria’s position in Christianity. It is a real stage to reduce socio-religious stereotype of waria.

Moreover, one of pastors visited Kebaya just to ask them about homosexuality. He came there because he was asked by his fellow about that issue, and he felt that Kebaya members know this more than himself. According to Mami VK,

${ }^{28}$ Interview with Mami VK, February 20, 2013, at Kebaya basecamp. 
Kebaya was really appreciative welcoming the pastor to discuss each other about homosexuality and Christian.

In addition to personal level, Kebaya also attended many agendas of waria empowerment by inviting elites of religious people, including pastors, to actively involve within it. For Mami VK, those programs are significant not only to provide a positive athmosphere among waria's life, but also to make peace interreligious building of dialogue with pastor.

\section{Waria and FPI}

FPI (Front Pembela Islam/Front of Islamic Defender) is also included in interfatih dialogue with waria in Yogyakarta. It seems surprisingly since that instead of having dialogue, FPI in other areas often involved in sweeping waria, as recently happened in Solo and Jakarta.

However, in Yogyakarta, Kebaya's proactive action in socialisation of waria's identity had a significant aspect for FPI's acceptance on them. Uniquely, Mami VK has a close relation with a staff leader of FPI, namely HR, as it is far easier and safer for attending various events regarding with waria in Yogyakarta.

I well befriend with some of FPI members. One of them is HR. I comfortably attended waria contest in front of Banteng Vredeburg because there is no worry for FPI's sweeping. In Kaliurang, there was a seminar talking about lesbian swept by FPI and I was there for giving acknowledgment. I found no bad or rough treatment. Later, I told HR about this and he just said: "It is better for your friends to be like you, having achievements and skills." I just answered, "Everyone is different. They have own advantages and disadvantages. Not everyone must be like me". ${ }^{29}$

Institutionally, Kebaya doesn't have close and formal relation with FPI, but personally Mami VK befriends with some members of FPI. It surely leads to more serious interreligious dialogues, especially for discussing how waria is considered by FPI members who tend to be rather radical.

For Mami VK, Kebaya is in fortune because it lies in Yogyakarta which is largely known as a city of tolerance even though there are recently issues concerning with local government policy to eliminate some ethnic groups, such as Papuan. Mami VK assumes that Yogyakarta is special than other cities. It also supports harmony between Kebaya and FPI up to now. "In other cities, waria is usually swept and raided, but it doesn't happen in Yogyakarta.

29 Interview with Mami VK, February 20, 2013, at Kebaya basecamp. 
That makes Yogyakarta special. I am sure everywhere here is safe. Meanwhile, in Jakarta and Solo, it is difficult to get a safe place for us," Mami VK said in end of our interview.

\section{PROMOTING INTERRELIGIOUS DIALOGUE}

There is lack of empirical adequacy to restrict the interreligious dialogue merely as encounter between waria and religious elites. More importantly, the ultimate goal is to make waria be aware of the importance of the interreligious dialogue in their daily lives. For this purpose, Mansour Fakih's perspective of transformation, as mentioned before, should be implemented in considering about the degrees to which Kebaya's empowerment to waria has effectively worked in the context of interreligious dialogue.

Some programs are considered as successful in empowering waria to involve themselves within interreligious dialogue. The following is a short depiction of each program and parameter on how far these programs are aimed to make them recognize the importance of building the interreligious dialogue.

\section{Gong Xi Fat Chai Parade}

The procession is carried out for one year in every Imlek. This is one of Kebaya programs of empowernment in appreciating Kong $\mathrm{Hu}$ Chu community. The program is intitutionally aimed for normative celebration between waria and Kong $\mathrm{Hu} \mathrm{Chu}$, but it has substantively provided an important effort to increase waria's consciousness of the importance of interreligious dialogue.

Through getting involved in the parade, waria can socially encounter with Kong $\mathrm{Hu} \mathrm{Chu}$ community, whose are also minority of social relation in Indonesia. Mami VK has stated that this procession has not merely dominated by the Kebaya as the main coordinator. This institution has only facilitated and coordinated the meeting of waria in Yogyakarta and attempted to seek for their own creative plans about the parade.

This parade is expected to be one of the strong factors in building relationship between waria and Kong $\mathrm{Hu} \mathrm{Chu}$. However, in the broader perspective of interreligious dialogue, this program has provided a space for dialogue among them. It means that Gong Xi Fat Chai parade has included idea of 'selfempowerment' in order to get waria involved in the interactive participation with Kong $\mathrm{Hu} \mathrm{Chu}$. They can recognize about their needs to not only actively participate together, but also to develop themselves in building a better interreligious dialogue. 


\section{Waria's Reunion in Cooperation with GKI Semarang}

Kebaya can be regarded as one of cultural institutions in Yogyakarta which actively involves in development of plurality and interreligious tolerance. Waria's Reunion is a program held by this NGO to empower waria in better understanding this religiosity. Interestingly, this program is resulted from the cooperation between Kebaya and GKI (Gereja Kristen Indonesia/Christian Chruch of Indonesia) Semarang.

Waria's reunion is initially aimed to strengthen a network of inter-waria in Yogyakarta and Semarang. However, it is strongly believed that this program can cultivate a progressive consciousness to build the interreligious dialogue. The reason is that this program has included one of big Christian communities in Semarang. It means that the interreligious dialogue can also be built through alumni networks.

This is why that Kebaya is very enthusiastic to not merely gaining a social beneficial from empowerment of waria within the own community. This NGO has efforts to build a network of interreligious community. As like as Gong Xi Fat Chai parade, the implementation of reunion is creatively handled by waria. It is a space for them to build an interfaith dialogue with Christian community in GKI Semarang. By doing this program, waria is expected to have religious consciousness about the importance of reunion not only for strengthening the network, but also for empowering themselves in the context of interreligious dialogue.

\section{FURTHER ANALYSIS}

\section{God and Personal Intimacy}

This research points out that waria's relation with God is still in personal level. Meaning to say, worship is still just interpreted as personal intimacy only so that it is performed in private places. ${ }^{30}$ They know how importance worship is, but it is not number one priority in interpreting God. They perform prayer, but they don't force others to do as they do, as well as to perform worshipping in public places.

It suggests that social stereotype really influences how they interpret and see God. Waria like to meet the God in lonely places where others can't reach the place and find them out. Mami VK and his friends' decision not to perform Friday prayer is a proof that a matter of social acceptance really troubles waria.

${ }^{30}$ Further explanation about personal intimacy can be read in Joe Masterlo's article, "Intimacy: Religion vs. Spirituality", http://www.joemasterleolcsw.com/2012/01/21/intimacyreligion-vs-spirituality/, accessed on March 12, 2013. 
Besides that, they accentuate religion on pleasantness in performing worship. This leads them to think that worship is a private matter of each individual. It is important to notice that they do worship as men. In performing prayer, they often use kopiah while in pilgrimage, they also act as men. Here, Mami VK plays a good role by forcing waria to consider themselves as men and not to lie to their selves by considering that they are women.

Interpreting God is often regarded with a matter of sin and destiny. On these two issues, Kebaya members are in different opinions about how God really treats them. In one hand, they are still bothered by orthodoxy doctrine about people of Lot's story regarded with them. This makes them less confidence to talk about God especially in a matter of their personality.

Meanwhile, on the other hand, some of them consider that being waria is not sinful because it is God's gift. For those who think like this, being waria is even a blessing because God had determined them to be as they are since they were born. Refusing it is refusing God's blessing they have received. This is such an undeniable destiny.

One time, Mami VKs was asked, "Does God think that you are a man, woman, or waria?" He simply answered, "God considers me as waria, neither man nor woman. Being waria is what God wants about me". Although this statement represents that they are the third gender beyond man and woman, actually they can't refuse or reject the fact they are normal men with feminine mind and thought in talking about sin and destiny.

\section{“Personal” Interreligious Dialogue}

Since it was firstly born and run, Kebaya has not been actively involved in building formal interreligious dialogues with elites of religious people. However, this doesn't mean that they never been involved in this kind of dialogue. In some chances, as it was explained before, they had dialogues with some elites of religious people. They are also often considered as more knowledgably one to talk about homosexuality instead of elites of religious people.

However, interreligious dialogue in Kebaya is still in personal scope. The dialogue is not formally and directly facilitated by Kebaya yet. It run and occurred individually, as what Mami VK experienced due to his board connection. He has good and intense communication with kyai, pastor, as well as FPI member. This close relationship facilitates him to be in intense interreligious dialogue with them all.

However, as Mami VK said, Kebaya is not proactive yet in building 
interreligious dialogues, and they just give a feedback so far. Meaning to say, they don't be proactively involved by visiting elites of religious people to talk to them formally and intentionally. Perhaps, the reason is because they feel it is enough to live their life without having to talk and interact with elites of religious people. Consequently, they are more often visited instead of going somewhere to visit anybody.

Besides that, interreligious dialogue of Kebaya only happened in Yogyakarta so far. Those who visit Kebaya are also from Yogyakarta only. This indicates that interreligious dialogue in this NGO is still in local level. Discussed topic is also about one same thing, i.e. homosexuality.

In various moments, as what Mami VK and his followers did in Seminari Yogyakarta and befriended with FPI, priest and pastor, Kebaya is also institutionally involved, although it is still facilitated by personal relationship and friends' link of Mami VK. Mami VK is playing important role here in building and keeping interreligious relationship between waria and elites of religious people.

Additionally, one thing to be concerned with interreligious dialogues is about minimum involvement of Al-Falah Islamic institution coordinated by this NGO. Mami VK herself admitted that Kebaya doesn't intervene anything about it.

If any buddy's here want to stay at the boarding, we please them. I don't force them at all. It was them who choose to stay here (Kebaya) or get living outside. I find no problem on that. I don't also intervene managerial of institution. I will attend in social programs but for educational or religious program, I seldom attend. ${ }^{31}$

It is noticable to infer that interreligious dialogue Kebaya attended is still in personal level, especially what happens to Mami VK and his close relationship with some elites of religious people. Surely, Mami VK has important role in keeping interreligious relation, besides his own skill and achievement enabling him to easily interact with society. He is a good beginning for building more serious interreligious dialogue in larger scope.

\section{“Critical” Interreligious Dialogue}

The critical dialogue assumes that empowerment of waria is aimed not only to involve waria in making responsibility for the others, but also to make themselves be aware of building an interreligious dialogue. The idea of 'critical'

\footnotetext{
${ }^{31}$ Interview with Mami VK, February 20, 2013, at Kebaya basecamp.
} 
is coming from Mansour Fakih's notion about transformative movement in society. This movement which is known as 'organic intellectual' acquires the communities' efforts to have critical attitude for social transformation.

In relation with waria, the critical dialogue is defined as waria's efforts in making them open with other people without having influence from external factors, such as their involvement in NGO. It means that Kebaya has a facilitating function to increase their consciousness in building the interreligious dialogue with the others. This is one of important steps for social transformation of waria in specific and social community in general.

The Gong Xi Fat Chai parade and Warias Reunion in cooperation with GKI Semarang is two of transformative agendas administered by Kebaya to make waria having collective consciousness to build an interreligious dialogue with other religious community. Furthermore, their institutional dependency on Kebaya can be decreased by means of their involvement in these progressive programs.

This critical movement which is aimed to create a social transformation has reflected itself within waria's creativity in developing their own activities of both programs. In addition to increase their self-rule, this movement is hopefuly to make waria be aware of the importance of their active participation in interreligious dialogue.

Indeed, it is too far to expect a "big result" from such programs. However, what Kebaya has done through these programs has reflected their efforts to be critical to themselves and their social community. For Mansour Fakih, this is "another way" (jalan lain) for every social institution, including Kebaya, not only to strengthen waria's social independency, but also to guide them in humanizing themselves in the context of interreligious dialogue.

Their involvement within these critical programs of empowerment is also a challenge to common institutions and educational policies which side with majority and discriminate minority groups. Instead of cultivating a spirit of interreligious dialogue, such institution has commonly been directed to create the single definition of the plurality and religiosity.

Regarding with this ironical condition, the concept of "interreligious dialogue" should be re-interpreted in broader spectrum. It is possible to build an interreligious dialogue if people who involve within this dialogue are not only able to be actively involved in the personal dialogue with religious elites, but also can empower themselves in making a critical interreligious dialogue for social transformation. 


\section{CONCLUSION AND SUGGESTION}

In social life, waria is often considered as abnormal people. However, their religious experiences as well as interreligious religion of their life are rarely exposed. Social stereotype runs without looking waria as religious people who also worship God. Few attentions on the religious aspect often make them more marginalized because if covers them and their life more and more, so they become more mysterious.

Actually, waria community members also have their own religious experiences. They also have own interpretation about God, worship, destiny, as well as sin. They worship in a deep personal intimacy. They also consider Him as One Essence wanting and determining them to be as they are. In spite of difference opinions on whether becomes waria is sinful, waria's relation with God is still limited in private public.

In interreligious dialog, Kebaya actively involved many times. Being facilitated and promoted by Mami VK, this NGO has tried to build good and harmonic relation with kyai, pastor and FPI. Although the dialogue is still in local scope, what Mami VK has done so far is a good start to the better condition.

Kebaya has further efforts to build social transformation through critical interreligious dialogue. This is carried out, one of them, by means of implementing two programs of empowerment, namely Gong Xi Fat Chai and Waria's Reunion in cooperation with GKI Semarang. Although they take ceremonial forms, both of them are expected to increase their attempts in building an interreligious dialogue. Through these programs, they are not only facilitated to have dialogue with religious elites, but also to encourage themselves in building their own interreligious dialogue.

For the next time, interreligious dialogue of this NGO should be broadened into community level, not personal only, so that religious experience can also be known by waria outside the NGO.[]

\section{BIBILIOGRAPHY}

Brooks, Hannah. 2011. "Warias, COme Out and Plaaayayay", http://www.vice. $\mathrm{com} / \mathrm{read} /$ warias-come-out-and-plaaayayay-0000007-v18n10. The last access: 15th, August 2016

Fakih, Mansour, Jalan Lain: Manifesto Intelektual Organik, Yogyakarta: Pustaka Pelajar bekerja sama dengan Insist Press, 2002.

Glaser, Chris. 2008. "Gender Identity and Our Faith Community." A Guide for Ad- 
vocacy, published by Human RIght Campaign. Online download: $h t t p: / /$ www.hrc.org/resources/gender-identity-and-our-faith-communities-a-congregational-guide-for-transg. The last access: August 15th, 2016.

Koeswinarno, Hidup sebagai Waria, Yogyakarta: LKiS, 2004.

Koeswinarno, "Islamic Response to Transexuality in Indonesia", a paper presented in Southeast Asian Consorsium on Gender, Sexuality, and Sexual Health, Salaya, Thailand, 2003.

Koeswinarno. 1996. Waria dan Penyakit Menular Seksual. Yogyakarta: Pusat Penelitian Kependudukan UGM.

Boellstorff, Tom, "Playing Back the Nation: Waria, Indonesia Transvestites", Cultural Anthropology, Vol. 19, No. 2 (Mei, 2004), pp. 159-195.

Boellstorff, Tom, "Between Religion and Desire: Being Muslim and Gay in Indonesia”, American Anthropologist, New Series, Vol. 107, No. 4 (Dec., 2005), pp. 575-585.

Tim LSM Kebaya, "Database Pendampingan Waria LSM Kebaya DIY Per-31 Mei 2011”, Yogyakarta: LSM Kebaya (unpublished).

Syam, Nur, Agama Pelacur: Dramaturgi Transendetal, Yogyakarta: LKiS, 2011

Murray, Stephen dan Will Roscoe, "Conclusion", Islamic Homosexualities: Culture, History, and Literature, (eds. Murray dan Roscoe), New York: New York University Press, 1997, pp. 302-319.

Murtagh, Ben. 2013. Genders and Sexualities in Indonesian Cinema: Contructing Gay, Lesbi, and Waria Identities on Screen. Abingdon, Oxon, New York: Routledge.

Masterleo, Joe, "Intimacy: Religion vs. Spirituality", http://www.joemasterleolcsw.com/2012/01/21/intimacy-religion-vs-spirituality/, diakses pada 12 Maret 2013.

Sunardi, “The Dead End of Religious Dialogue in Indonesia”, Interface 4, 1 Mei 2001, pp. 55-65. 
